$\xi=1$

\title{
Quantitative and Qualitative Approaches in Managing Human Resource Development in Enterprises
}

\author{
Iryna Buzko $^{1}$, Yuriy Dyachenko ${ }^{1 *}$, Ievgen Ovcharenko ${ }^{1}$, Yuliia Klius ${ }^{1}$ \\ ${ }^{I}$ Volodymyr Dahl East Ukrainian National University, Severodonetsk, Ukraine \\ *Corresponding author E-mail: y.dyachenko@i.ua
}

\begin{abstract}
The paper proposes comparing the existing and the required level of competence of the employee as a tool for determining the qualitative and quantitative parameters of personnel training. To implement this comparison, in accordance with official requirements, the human capital required for the performance of official duties as an employee's quality, which acquires value in the process of attracting to industrial relations, is calculated. Qualitative and quantitative parameters of personnel training are determined on the basis of calculation of the difference between necessary and existing competence taking into account financial possibilities of the enterprise. According to the results of calculating the available human capital, which a certain employee owns, and comparing it with the necessary one, the content (according to the type of insufficient capital) and the amount (by difference between the existing and the required level) of training, which should bring the available human capital of the employee in accordance with the required one. Formation of the content of the training is based on the definition of individual assets of human capital, which depend on the requirements for the competence of the employee and can be changed through training.
\end{abstract}

Keywords: Enterprise management; Human capital; Human resource development; Personnel training.

\section{Introduction}

Acceleration of globalization processes at the end of the 20th century became a catalyst for the emergence of a new type of economic environment - a knowledge-based economy, and the country's ability to create knowledge (primarily scientific), its dissemination and effective use for the development of production and society, within such an economy are becoming the main growth factors along with traditional sources - investments and labor resources, significantly increasing the efficiency of their use [24]. Education is a basic industry for the transition to an innovative model of economic development, for the development of a knowledge-based economy and the problem of improving the workforce today is not limited to the training of employees in certain professions, and modern economy and flexible labor market require a new quality of education and professional training [24].

\section{Modern Methods of Determining the Effec- tiveness of Personnel Training}

The basis for managing personnel development lies in determining its effectiveness. According to the theory of human capital, the cost of professional training is considered an investment in human capital by organizations and should bring a return in the form of increasing the enterprise efficiency [3]. Determining the costs of training and its effectiveness is necessary to compile and justify the training budget as a component of the enterprise budget. For compiling you need to determine when, how much and what resources you need for training implementation. To protect the train- ing budget, it is necessary to determine the costs and incomes, that is, the quantitative analysis of effectiveness. Also, determining the costs of training and its effectiveness is necessary in order to select and further improve the types and methods of training.

The most common methods for determining the effectiveness of personnel development system are benchmarking methods, key performance indicators and a balanced scorecard system. These methods provide a number of key performance indicators (KPI) which characterize the personnel development system, they are calculated and analyzed in one of two ways: comparison with similar indicators in other units or enterprises, which is a benchmarking method, or the analysis of the dynamics of indicators for the unit or enterprise as a whole, which are the methods of key indicators of effectiveness and a balanced scorecard system.

The advantage of the method of key performance indicators is visibility and quantitative nature of indicators, which allow for a detailed analysis of the dynamics of indicators. The disadvantage is the impossibility of a completely objective comparison due to the influence of external factors and rather significant financial and time costs for the development of methodology [2] and, particularly, for calculation of indicators.

Training costs are divided into three types: direct, indirect and implicit costs [26]. Direct costs for personnel training include the remuneration of training and support personnel; costs for preparation and distribution in printed or electronic form of informational and methodical materials in the form of textbooks, training aids, auxiliary materials, as well as software; training fee if it takes place outside the enterprise. Indirect costs for personnel training include the costs of purchasing or renting premises and equipment, which includes information and communication one; costs related to business trips. Implicit costs consist of wages (during training period) of those who are training, production loss due to absentee- 
ism of those who are training in the workplace [26], as well as losses due to the impossibility of alternative use of training facilities and technical training aids.

The cost-effectiveness analysis of personnel development is carried out by means of static comparison with the corresponding indicators of the same size and type of enterprise activity of the same field or considering the dynamics of changes over a certain period of time at this enterprise. These indicators can also be used to make decisions about investing in personnel by choosing the options with the highest savings in relation to investments or the shortest payback period.

Along with direct, there are indirect or transaction costs for personnel development. Economic science owes the notion of transaction or non-production costs to new institutional theory. Transaction costs in broad sense are considered as interaction costs in the economic system and are associated with the uncertainty of market agents' behavior and the economic situation as a whole in the process of contracting and contract enforcement. The theory of transaction costs was proposed to refine the economic models of the neoclassical theory of the firm. According to neoclassical theory of the firm, the functioning of the economic mechanism occurs without costs of using economic mechanisms, in the real economy there exist such costs for contracts servicing and they are called transaction costs.

Consider the transaction costs associated with training.

In the process of training transaction costs associated with, in particular, the complexity of objective personnel assessment, possible inaccuracies in such an assessment, the difficulty of controlling the training effectiveness and significantly affect the effectiveness of personnel training.

Transaction costs related to training can be divided into two categories: related to personnel involvement: recruitment; transfer from one workplace to another and related to the use of human capital: personnel disposition; use of personnel; development of personnel; control of the level of personnel competence.

Particularly, in the process of investing in human capital, the following transaction costs can be distinguished:

- search, collection and evaluation of information about: the available human capital of the company's personnel; the proposed human capital during recruitment; the human capital needed for production, taking into account the strategy of enterprise development and forecasts of market conditions and macroeconomic indicators;

- making decisions on increasing human capital through personnel development or recruiting personnel from outside;

- controlling the increase of human capital during personnel development and involving acquisition of personnel.

In detail, it is possible to list the following transaction costs arising in connection with personnel training:

- costs for estimating the volume of human capital required for an enterprise, taking into account the strategy of enterprise development and forecasts of market conditions and macroeconomic indicators;

- costs for estimating the volume of human capital available at the enterprise to compare it with the required volume of human capital; - costs for collecting information to make decisions about recruitment, development or efficient displacement of personnel in case a certain number of personnel of a certain qualification is required;

- costs for making decisions on recruiting or development of personnel in conditions of uncertainty.

- costs for controlling the process and the results of personnel development and the calculation of training efficiency.

We offer the ways to reduce transaction costs by investing in social capital.

The use of social capital can reduce the loss from objective uncertainty associated with incomplete information and unpredictability of market environment in case of the possibility of obtaining the necessary information with a better quality. Reducing losses from subjective uncertainty caused by possible opportunistic actions of partners is possible due to generally accepted rules of conduct: unwritten norms and trust relationship. Thus, the use of social capital can be assumed as a means of reducing transaction costs.

\section{The Role to Social Capital in Improving the Effectiveness of Training}

An important way of reducing transaction costs is to ensure the effectiveness of personnel training through the creation of conditions for interaction and cooperation of employees in the process of personnel training, which helps reduce the losses caused by objective uncertainty associated with incomplete information and unpredictability of market environment. Reducing losses from subjective uncertainty caused by possible opportunistic actions of partners is possible by stimulating investment in social capital, ensuring the maintenance of generally accepted rules of conduct: unwritten norms and trust relationship. Let us analyze social capital as an indicator of the effectiveness of employee interaction. [65].

The division of the capital into physical, human and social associated with identification of productive qualities of means of production, productive qualities of man and productive qualities of interpersonal relations, created as a result of investment and bring income, which is generated in the process of production. If the human capital of an enterprise is the sum of knowledge, skills and abilities of employees, then social capital characterizes the productive value of the relationship between employees. The foundation of social capital is trust, which is defined as "expected reciprocity" and gives confidence that efforts aimed at helping others will be recognized and paid off [15]. The presence of trust between economic actors allows them to reduce operating and transaction costs for their activity. Social capital as an attribute of social connection of individuals is defined and studied, in particular, by using economic principles of rational behavior in social systems analysis.

Summarizing the considered definitions of social capital and the opinions of scientists in this regard, it is possible to conclude that the economic network, which consists of certain individuals- social, or of enterprises- economic, is characterized, in particular, by a certain amount of social capital, which is defined as the amount of costs for creation and maintenance of economic network and investment in exteriorized network human capital. In its turn, the direct costs for the network consist of time and material costs for creation and maintenance of network. The time spent on creating and maintaining a network is the economic equivalent of time spent on creating and maintaining a network. That is, social capital can be calculated according to the following formula:

$\mathrm{SC}=\mathrm{C}_{\mathrm{n}}+\mathrm{HC}_{\mathrm{n}}=\mathrm{T} \cdot \mathrm{c}_{\mathrm{t}}+\mathrm{C}_{\mathrm{nm}}+\mathrm{HC}_{\mathrm{n}}$,

where $\mathrm{C}_{\mathrm{n}}-$ costs for creating and maintaining an economic network; $\mathrm{HC}_{\mathrm{n}}$ - investments in exteriorized network human capital; $\mathrm{T}$ - time spent on creating and maintaining a network; $\mathrm{c}_{\mathrm{t}}-$ time cost; $\mathrm{C}_{\mathrm{nm}}$ - material costs for creating and maintaining a network.

The alternative costs associated with functioning of network include the loss of income due to impossibility of opportunistic behavior.

Income from social capital is determined by the following components:

- reduction of transaction costs as a result of reduction of the probability of opportunistic actions of the network participants in comparison with the participants of economic relations which are not part of the network; the increase in the probability of a successful completion of the planned actions as a result of increased predictability of relations between actors due to network norms of conduct. Investing in social capital is a protection against uncertainty in market relations and a way of reducing transaction costs; - return on exteriorized network human capital in the form of increase of income from economic activity due to :greater aware- 
ness; access to exteriorized network human capital; increase of effectiveness of collective action.

A significant number of studies relate to the impact of social capital on the creation of human capital in the educational process. In particular, the "educational level of the family" is decomposed into financial capital, human capital and social capital [4]. Financial capital is measured by family wealth and income. It helps create a study place at home, the learner is provided with study materials and manuals, family problems are smoothed out by financial resources. Human capital is measured by the education of parents and helps explore the world around us, contributes to the learning process. The social capital of a family is the relationship between children and parents (a combination of certain elements, such as the presence of both parents, the number of brothers and sisters and the expectations of parents about the education of their child).

When investing in social capital, it is important to analyze the mutual influence of education, social capital and transaction costs. If we consider the role of social capital in education, particularly higher and professional, then, apart from the transfer of knowledge, rules, methods, education is a process of teaching moral norms, thanks to which professional standards are placed above own interests of a professional. Such education cultivates certain norms that become an important source of social capital [7] In the field of education, the main mechanisms of social relations are social cohesion and sociability.

At work employees learn from each other in the workplace. This process is stimulated in a collective work, where new team members learn in the workplace under the guidance of more experienced employees. Another form of by-effect of learning is the joint development and rapid transfer of new technologies through collective learning, for example, through business networks [21] In both ways: an increase in the average level of human capital and the transfer of new technologies, - social cohesion and sociability stimulate the growth of incomes and thereby increase the overall productivity of production factors [14]. Information transfer is also facilitated under conditions of confidence that helps to overcome transaction costs in the transfer process and if the participants come from countries with a high level of trust, they tend to have more learning opportunities because they are parties to large and rich information flows [5, p. 31]. According to Putnam [22], informal education in groups and organizations improves the quality of life and develops social ties, relationships of trust and tolerance, consequently increasing social capital. On the other hand, as J. Coleman has shown in his study, there is a reciprocal interaction: social capital affects learning success: those who study in a supportive social environment have a greater probability of graduation [4]. That is, it is the high level of social capital that reduces transaction costs and contributes to the successful learning and growth of human capital.

Important is the study of the influence of emergence and spread of information and communication technologies on the creation of social capital. In our opinion, the availability of these funds leads to a reduction in transaction costs and the growth of social capital. It also seems useful to conduct an analysis of the influence of information and communication technologies on the profitability of social capital. Social networks, the creation of which is greatly facilitated with the emergence of widespread access to the Internet, can lead to the accumulation of a significant amount of social capital, which can be used for training and accumulation of human capital.

One of the first to draw attention to the economic value of network relations was American sociologist Mark Granovetter [8], noting that economic behavior "is included in the network of interpersonal relations". Granovetter noted that the success of job search depends on their interpersonal relations: individuals with a large number of informal (weak) ties find work easier than those who have only regular (strong) ties [9]. Perhaps this approach can be fruitful when considering access to information resources in a wider context, particularly in the training process. According to
American sociologists Paul DiMaggio and Walter Powell, for individuals with a wide range of weak ties, on-the-job training process is simplified [6]. Acquisition and use of knowledge to a large extend depend on the density and quality of external, not related to official duties, professional relationships within the firm and with specialists from other firms [25, 23]. Training is largely taking place in the process of inheriting best practices transmitted through social networks, allowing saving transaction costs associated with information search [6]. According to many researchers, networks simplify the training process for both individuals and organizations.

Public policy in stimulating social capital growth should be cautious about measures that encourage multiculturalism and programs that weaken the level of social responsibility and solidarity, and must ensure public security and stability of property rights, that is reducing transaction costs for economic agents [7].

Consider the dynamics of the accumulation of social capital. In the second half of the twentieth century, Putnam shows a trend towards a decline in social capital [22]. Consider the possible reasons for this. Historically, in the twentieth century the following social and economic trends can be noted:

- development of processes that reduce uncertainty and loss from it by reducing transaction costs for economic agents and transferring them to public institutions [27];

- distribution of information and communication technologies and technical means of receiving, distributing and processing information: telephone, Internet, personal computers, mobile communication.

These aspects, reducing uncertainty, reduce losses from the latter, leading to a reduction in the need for social capital, which neutralizes uncertainty. The security provided to the actor at the institutional level reduces the need for investment in social capital, which provided security before, so informal social structures of protection against uncertainty are replaced by formal institutional ones.

In addition, the decline of social capital can be explained by the substitution effect of increasing wages and, consequently, of underinvestment in social capital. As Becker has shown, an increase of wages, due to the substitution effect, leads to a reduction in time for non-production activities [1], which can include investment in social capital: people prefer to spend more time at work, increasing their income instead of establishing and maintaining social contacts outside of it. However, this conclusion does not refer to social capital, which is directly linked to production activity, and the investment to which may increase with the increase of wages. One of the ways of measuring social capital is Fukuyama's proposal to evaluate the value of product made by a given social group [7].

\section{Methods of Determining the Effectiveness of Training.}

Consider the ways to determine the effectiveness of training. The basic model for determining the effectiveness of training is the Kirkpatrick model [10-13].

At the first level, the assessment is determined by the reaction of the participants and customers of the program, which is according to D. Kirkpatrick, "assessment of consumer satisfaction" through a survey of participants and customers of the program. Conducted immediately after graduation or employee's return from training. May include questions on the assessment of the following aspects [26]: awareness of participants about the future training, time, place and training facilities, the benefit of training, technical training aids, teaching, the ability to apply the gained knowledge and skills at work.

At the second level, the acquired knowledge, changes in the settings, the improvement of knowledge and skills of the participants are determined. Such assessment is carried out before and imme- 
diately after training through testing of knowledge, skills and abilities: tests, exams, cases and at the assessment center.

At the third level, an assessment of changes in the behavior of participants is made with the desire to change behavior, the availability of knowledge about proper behavior and facilitating changes in behavior from team and administration. An assessment is made on the basis of an analysis of the opinions and testimonials of managers [18], colleagues and customers. Typically, such an analysis is carried out before the training and two weeks later, when knowledge, skills and abilities acquired are used in practice and after 1-2 months when knowledge, skills and abilities are to become stable.

At the fourth level, the influence of training on the functioning of the enterprise is assessed by measuring the quantitative but not financial influence of training on the functioning of enterprise, for example, productivity growth, quality growth, reduction of rejection rate, reduction of the number of accidents, etc. The assessment is carried out 6-12 month after the end of training. For this purpose the following is being recorded $[19,26]$ : dynamics of profit indicators, dynamics of stability of enterprise position in the market, changes in intellectual capital, image and reputation improvement, growth of labor productivity, increase of sales volume, quality improvement, reduction of rejection rate, calculation of "return of expectations" (ROE). For a quantitative non-financial assessment of training effectiveness, the indicator ROE of return expectations is used, that is, the expected change in certain indicators after training. Absolute "return expectations" ROE is calculated using the following formula:

$$
\mathrm{ROE}=\mathrm{p}_{2}-\mathrm{p}_{1},
$$

where $\mathrm{p}_{1}$ - indicator before conducting the training; $\mathrm{p}_{2}$ - indicator after conducting the training.

Relative "return of expectations" ROE is calculated as follows:

$$
\mathrm{ROE}=\frac{\mathrm{p}_{2}-\mathrm{p}_{1}}{\mathrm{p}_{1}} \cdot 100=100 \cdot\left(\frac{\mathrm{p}_{2}}{\mathrm{p}_{2}}-1\right) .
$$

The analysis of the results of the first-level assessment of Kirkpatrick, that is, response to training, enables [26] to find and eliminate the causes of employee dissatisfaction with training;

Analysis of learning outcomes at the first-third levels (training) allows to:

- assess the quality of education;

- assess the provider of training services;

- have the opportunity to improve the training process in the future; - control the discipline and integrity of those who train.

Calculation of ROI enables to give an overall assessment of the effectiveness of training and the validity of its content, scope, and time.

The development of the Kirkpatrick model is the Phillips model, that is, the calculation of return of investment ROI.

In the 70's and 80's, John F. Phillips, HR Manager, developed a fifth , additional to four-level model of Kirkpatrick, level - "return on investment" (ROI) [20]. By the Phillips formula, ROI is calculated as:

$$
\mathrm{ROI}=\frac{\mathrm{P}-\mathrm{V}}{\mathrm{V}} \cdot 100=100 \cdot\left(\frac{\mathrm{P}}{\mathrm{V}}-1\right),
$$

where $\mathrm{P}$ - income from training programs; $\mathrm{V}$ - the cost of training programs.

The cost of training programs should include both transformational, i.e. direct costs, and indirect -transaction, that is:

$$
\mathrm{V}=\sum_{\mathrm{i}=1}^{\mathrm{n}} \mathrm{v}_{\mathrm{i}}
$$

where $v_{i}$-individual direct and indirect cost of training .
According to the ROI method, the following steps are taken to determine the training effectiveness:

- information is collected for the evaluation of the first four levels of the Kirkpatrick model;

- the effects of training are isolated from other factors affecting the outcome;

- the influence of training is confirmed or not confirmed qualitatively;

- if the influence of training is confirmed, then the training outcomes are transferred into financial indicators: the so-called "hard" indicators: product received, quality, working time, costs; and the so-called "soft" indicators: psychological climate, relationships in the team, initiative and habits;

- the amount of training costs is calculated;

- ROI is calculated according to (4).

Non-financial quantitative performance indicators $\mathrm{K}_{1}, \mathrm{~K}_{2}, \ldots, \mathrm{K}_{\mathrm{j}}, \ldots$, $\mathrm{K}_{\mathrm{k}}$ : terms of performing operations, relative value of personnel errors, etc. can also be used for financial evaluation of the effectiveness of training programs. Indicate the changes in the relevant quantitative performance indicators as $\Delta \mathrm{K}_{1}, \Delta \mathrm{K}_{2}, \ldots, \Delta \mathrm{K}_{\mathrm{j}}, \ldots, \Delta \mathrm{K}_{\mathrm{k}}$. To convert quantitative performance indicators into financial indicators we use the specific conversion coefficients: $f_{1}, f_{2}, \ldots, f_{j}, \ldots$, $\mathrm{f}_{\mathrm{k}}$. Under these conditions, the income from training programs

$$
P=\sum_{j=1}^{k} \Delta K_{j} \cdot f_{j}
$$

In this case, the return on investment:

$$
R O I=\frac{\sum_{j=1}^{k} \Delta K_{j} \cdot f_{j}-V}{\sum_{i=1}^{n} v_{i}} \cdot 100=100 \cdot\left(\frac{\sum_{j=1}^{k} \Delta K_{j} \cdot f_{j}}{\sum_{i=1}^{n} v_{i}}-1\right) .
$$

When calculating ROI we face the following difficulties: the amount of income depends on many factors, to exclude the impact of which under real enterprise conditions is impossible; income from the project is sometimes of a hidden nature and is shown over a long period of time, so the calculation period should be quite long; it is difficult to convert the results into monetary income.

A qualitative or quantitative assessment of training enables [10-13] to explain the contribution of personnel and its structures to the achievement of the goals and objectives of the enterprise and to obtain information for decision-making on the continuation, modification of the form and content, or the completion of training programs. As benefits of training can be considered [19]:

- direct benefits: reduction of direct costs, increase of personnel productivity, reduction of time costs, product quality improvement - indirect benefits: production improvement ( shortening of time for information on interruptions, reducing absenteeism, reducing the number of safety violations ), stimulating personnel creativity, improving the quality of manpower ( reducing personnel turnover, complaints, dissatisfaction, increasing opportunities for career development );

- implicit benefits: improvement of the emotional component of personnel work, increased initiative and leadership qualities, improvement of basic communication skills .

The higher the cost of the training program, the higher is the level according to which they are evaluated. The following approaches can be used to reduce the evaluations costs [20]: imbedding evaluation in the training process, using special software [16] and examples for calculating quantitative indicators [17]. Evaluation can be implemented at different levels: from the individual components of the training course to the company's training projects for a certain period of time (usually a year).

Increasing the effectiveness of training is possible by increasing the efficiency of training in the form of income from training pro- 
grams, in particular through reducing transaction costs in production activities and reducing the costs of training in the form of transformation costs- the cost of training and transaction costs in the training process. Accordingly, in order to increase the training outcomes, it is necessary to train knowledge, skills and abilities that will reduce the transaction costs of production and training and to train the most important for production knowledge, skills and abilities.

Reducing the cost of training is possible because of minimizing the cost of training organization when choosing an organizational form of training and reducing transaction costs in the training process. Consider the calculation of the effectiveness of training, in particular, the influence of personnel training on the profit of the enterprise. In the event that the company loses its funds due to the insufficient educational and professional level of employees, personnel training with the cost of $\mathrm{C}_{\mathrm{tr}}$ is organized to improve the quality of work. After completing the training, the profit growth was $\Delta \mathrm{P}$, in this case the efficiency of personnel training

$\mathrm{R}=\Delta \mathrm{P}-\mathrm{C}_{\mathrm{tr}}$.

Effectiveness of training:

$\mathrm{ROI}=\left(\Delta \mathrm{P} / \mathrm{C}_{\mathrm{tr}}\right) \cdot 100$

\section{Practical Determination of the Effectiveness of Training of Industrial Enterprises Per- sonnel}

The most difficult task is to determine the effectiveness of training due to the segregation of costs for it and the complex feedback, due to the improvement of production results of the trained personnel. The period during which the training outcomes affect the performance of the enterprise depends on many external, in relation to enterprise, factors. Considering the fact that the identification of financial capacity for personnel training and the implementation of training take some time, changes in the financial position of the enterprise have a certain delay on the indicators that characterize the personnel training. In order to determine the impact of enterprise performance indicators on the indicators characterizing personnel training, an analysis has been carried out of the relationship between the performance indicators of machine-building and metallurgical enterprises, such as LLC Severodonetsk Plant of Chemical non-standardized Equipment (LLC "SZHNO", Table 1), PJSC Krasnyi Luch Mashine-building Plant (Table 2), PJSC Stakhanov Ferroalloy Plant (JSC "SZF", Table 3) and indicators characterizing personnel training.

Table 1: Financial results of activity, the size of the wage fund and the share of employees who completed the training at LLC "SZHNO" in 2007-2013

\begin{tabular}{|c|c|c|c|c|c|c|c|}
\hline Indicator & $\begin{array}{l}20 \\
07\end{array}$ & $\begin{array}{l}20 \\
08\end{array}$ & $\begin{array}{l}20 \\
09\end{array}$ & $\begin{array}{l}20 \\
10\end{array}$ & $\begin{array}{l}20 \\
11\end{array}$ & $\begin{array}{l}20 \\
12\end{array}$ & $\begin{array}{l}20 \\
13\end{array}$ \\
\hline Number of employees, people & $\begin{array}{c}23 \\
1 \\
\end{array}$ & $\begin{array}{c}27 \\
4 \\
\end{array}$ & $\begin{array}{c}27 \\
2 \\
\end{array}$ & $\begin{array}{c}27 \\
2 \\
\end{array}$ & $\begin{array}{c}27 \\
3 \\
\end{array}$ & $\begin{array}{c}31 \\
4 \\
\end{array}$ & $\begin{array}{c}32 \\
1\end{array}$ \\
\hline Wage fund, thsd. hrn. & $\begin{array}{c}42 \\
54 . \\
0\end{array}$ & $\begin{array}{c}58 \\
49 . \\
6\end{array}$ & $\begin{array}{c}27 \\
18 . \\
2\end{array}$ & $\begin{array}{c}50 \\
44 . \\
5\end{array}$ & $\begin{array}{c}60 \\
78 . \\
6\end{array}$ & $\begin{array}{c}71 \\
09 . \\
6\end{array}$ & $\begin{array}{c}68 \\
49 \\
8\end{array}$ \\
\hline $\begin{array}{l}\text { Wage fund per person, thousand hrn. } \\
\text { per person }\end{array}$ & $\begin{array}{l}18 . \\
42\end{array}$ & $\begin{array}{l}21 . \\
35\end{array}$ & $\begin{array}{c}9.9 \\
9\end{array}$ & $\begin{array}{l}18 . \\
55\end{array}$ & $\begin{array}{l}22 . \\
27\end{array}$ & $\begin{array}{l}22 . \\
64\end{array}$ & $\begin{array}{l}21 . \\
34\end{array}$ \\
\hline Net income, thsd. hrn. & $\begin{array}{c}25 \\
74 \\
0 \\
\end{array}$ & $\begin{array}{c}49 \\
75 \\
2 \\
\end{array}$ & $\begin{array}{c}46 \\
25 \\
0 \\
\end{array}$ & $\begin{array}{c}47 \\
23 \\
3 \\
\end{array}$ & $\begin{array}{c}76 \\
62 \\
8 \\
\end{array}$ & $\begin{array}{c}70 \\
13 \\
7 \\
\end{array}$ & $\begin{array}{c}96 \\
64 \\
9 \\
\end{array}$ \\
\hline Profit, thsd. hrn. & $\begin{array}{c}- \\
95 \\
9\end{array}$ & $\begin{array}{l}60 \\
22\end{array}$ & $\begin{array}{l}18 \\
23\end{array}$ & $\begin{array}{c}- \\
68 \\
25\end{array}$ & $\begin{array}{l}57 \\
11\end{array}$ & $\begin{array}{l}70 \\
36\end{array}$ & $\begin{array}{c}10 \\
76 \\
6\end{array}$ \\
\hline Profit per person, thsd. hrn. per person & $\begin{array}{c}- \\
4.1 \\
5\end{array}$ & $\begin{array}{l}21 . \\
98\end{array}$ & $\begin{array}{c}6.7 \\
0\end{array}$ & $\begin{array}{c}- \\
25 . \\
09\end{array}$ & $\begin{array}{l}20 . \\
92\end{array}$ & $\begin{array}{l}22 . \\
41\end{array}$ & $\begin{array}{l}33 . \\
54\end{array}$ \\
\hline $\begin{array}{l}\text { Number of employees who completed } \\
\text { advanced professional training, people }\end{array}$ & 49 & 46 & 36 & 25 & 43 & 42 & 21 \\
\hline
\end{tabular}

\begin{tabular}{|c|c|c|c|c|c|c|c|}
\hline $\begin{array}{c}\text { The share of employees who complet- } \\
\text { ed professional training, } \%\end{array}$ & $\begin{array}{c}21 . \\
2\end{array}$ & $\begin{array}{c}16 . \\
8\end{array}$ & $\begin{array}{c}13 . \\
2\end{array}$ & 9.2 & $\begin{array}{c}15 . \\
8\end{array}$ & $\begin{array}{c}13 . \\
4\end{array}$ & 6.5 \\
\hline $\begin{array}{c}\text { Change in wage fund, thsd.hrn per } \\
\text { year }\end{array}$ & & $\begin{array}{c}37 . \\
5\end{array}$ & $\begin{array}{c}- \\
53 . \\
5\end{array}$ & $\begin{array}{c}85 . \\
6\end{array}$ & $\begin{array}{c}20 . \\
5\end{array}$ & $\begin{array}{c}17 . \\
0\end{array}$ & 3.7 \\
\hline $\begin{array}{l}\text { Change in wage fund per person, } \\
\text { thsd.hrn. per person per year }\end{array}$ & & 15.9 & 53.2 & 85.6 & 20.1 & 1.7 & -5.8 \\
\hline $\begin{array}{l}\text { Change of net income. thsd.hrn. per } \\
\text { year }\end{array}$ & & $\begin{array}{c}93 . \\
3\end{array}$ & 7.0 & 2.1 & $\begin{array}{c}62 . \\
2\end{array}$ & 8.5 & $\begin{array}{c}37 . \\
8\end{array}$ \\
\hline Change of profit, thsd.hrn. per year & & $\begin{array}{l}72 \\
7.9\end{array}$ & $\begin{array}{c}- \\
69 . \\
7\end{array}$ & $\begin{array}{c}- \\
47 \\
4.4\end{array}$ & $\begin{array}{l}18 \\
3.7\end{array}$ & $\begin{array}{c}23 . \\
2\end{array}$ & $\begin{array}{c}53 . \\
0\end{array}$ \\
\hline $\begin{array}{c}\text { Change of profit per person, thsd.hrn. } \\
\text { per person per year }\end{array}$ & & $\begin{array}{l}62 \\
9.4\end{array}$ & $\begin{array}{c}- \\
69 . \\
5\end{array}$ & $\begin{array}{c}- \\
47 \\
4.4 \\
\end{array}$ & $\begin{array}{l}18 \\
3.4\end{array}$ & 7.1 & $\begin{array}{c}49 . \\
7\end{array}$ \\
\hline
\end{tabular}

The conducted analysis made it possible to determine the influence of particularly financial results on the scope of personnel training (Tables 4, 5).

Table 2: Financial results of activity, the size of the wage fund and the share of employees, who completed the training at PJSC Kransyi Luch Machine-building Plant in 2007-2013

\begin{tabular}{|c|c|c|c|c|c|c|c|}
\hline Indicator & $\begin{array}{l}20 \\
07\end{array}$ & $\begin{array}{l}20 \\
08\end{array}$ & $\begin{array}{l}20 \\
09\end{array}$ & $\begin{array}{l}20 \\
10\end{array}$ & $\begin{array}{l}20 \\
11\end{array}$ & $\begin{array}{l}20 \\
12\end{array}$ & $\begin{array}{l}20 \\
13\end{array}$ \\
\hline Number of employees, people & $\begin{array}{c}88 \\
9\end{array}$ & $\begin{array}{c}66 \\
5\end{array}$ & $\begin{array}{c}46 \\
4\end{array}$ & $\begin{array}{c}42 \\
6\end{array}$ & $\begin{array}{c}45 \\
6\end{array}$ & $\begin{array}{c}37 \\
1\end{array}$ & $\begin{array}{c}35 \\
2\end{array}$ \\
\hline Wage fund, thsd. hrn. & $\begin{array}{l}74 \\
49\end{array}$ & $\begin{array}{l}82 \\
01\end{array}$ & $\begin{array}{l}49 \\
15\end{array}$ & $\begin{array}{l}67 \\
08\end{array}$ & $\begin{array}{l}98 \\
15\end{array}$ & $\begin{array}{l}80 \\
21\end{array}$ & $\begin{array}{l}88 \\
00\end{array}$ \\
\hline $\begin{array}{l}\text { Wage fund per person, thousand hrn. } \\
\text { per person }\end{array}$ & $\begin{array}{c}8.3 \\
8\end{array}$ & $\begin{array}{l}12 . \\
33\end{array}$ & $\begin{array}{l}10 . \\
59\end{array}$ & $\begin{array}{l}15 . \\
75\end{array}$ & $\begin{array}{l}21 . \\
52\end{array}$ & $\begin{array}{l}21 . \\
62\end{array}$ & $\begin{array}{l}25 . \\
00\end{array}$ \\
\hline Net income, thsd. hrn. & $\begin{array}{c}33 \\
89 \\
8\end{array}$ & $\begin{array}{c}38 \\
38 \\
7\end{array}$ & $\begin{array}{c}13 \\
67 \\
9\end{array}$ & $\begin{array}{c}20 \\
99 \\
8\end{array}$ & $\begin{array}{c}46 \\
65 \\
9\end{array}$ & $\begin{array}{c}41 \\
16 \\
0\end{array}$ & $\begin{array}{c}40 \\
53 \\
1\end{array}$ \\
\hline Profit, thsd. hrn. & $\begin{array}{c}37 \\
9\end{array}$ & $\begin{array}{c}- \\
16 \\
02\end{array}$ & $\begin{array}{c}- \\
79 \\
2\end{array}$ & $\begin{array}{l}- \\
42 \\
58\end{array}$ & $\begin{array}{c}52 \\
9\end{array}$ & $\begin{array}{c}- \\
12 \\
44\end{array}$ & $\begin{array}{l}- \\
51 \\
01\end{array}$ \\
\hline Profit per person, thsd. hrn. per person & $\begin{array}{c}- \\
0.4 \\
3\end{array}$ & $\begin{array}{c}- \\
2.4 \\
1\end{array}$ & $\begin{array}{c}- \\
1.7 \\
1\end{array}$ & $\begin{array}{c} \\
10 . \\
00\end{array}$ & $\begin{array}{c}1.1 \\
6\end{array}$ & $\begin{array}{c}- \\
3.3 \\
5\end{array}$ & $\begin{array}{c}- \\
14 . \\
49\end{array}$ \\
\hline $\begin{array}{l}\text { Number of employees who completed } \\
\text { advanced professional training, people }\end{array}$ & $\begin{array}{c}43 \\
5\end{array}$ & $\begin{array}{c}27 \\
5\end{array}$ & $\begin{array}{c}20 \\
9\end{array}$ & $\begin{array}{c}26 \\
7\end{array}$ & $\begin{array}{c}25 \\
1\end{array}$ & $\begin{array}{c}18 \\
6\end{array}$ & $\begin{array}{c}17 \\
6\end{array}$ \\
\hline $\begin{array}{l}\text { The share of employees who completed } \\
\text { professional training, } \%\end{array}$ & $\begin{array}{c}48 . \\
9\end{array}$ & $\begin{array}{c}41 . \\
4\end{array}$ & $\begin{array}{c}45 . \\
0\end{array}$ & $\begin{array}{c}62 . \\
7\end{array}$ & $\begin{array}{c}55 . \\
0\end{array}$ & $\begin{array}{c}50 . \\
1\end{array}$ & $\begin{array}{c}50 . \\
0\end{array}$ \\
\hline Change in wage fund, thsd.hrn per year & & $\begin{array}{c}37 . \\
5\end{array}$ & $\begin{array}{c}- \\
53 . \\
5\end{array}$ & $\begin{array}{c}85 . \\
6\end{array}$ & $\begin{array}{c}20 . \\
5\end{array}$ & $\begin{array}{c}17 . \\
0\end{array}$ & 3.7 \\
\hline $\begin{array}{l}\text { Change in wage fund per person, } \\
\text { thsd.hrn. per person per year }\end{array}$ & & 15.9 & 53. & 85.6 & 20.1 & 1.7 & -5.8 \\
\hline $\begin{array}{l}\text { Change of net income. thsd.hrn. per } \\
\text { year }\end{array}$ & & \begin{tabular}{c|}
93. \\
3
\end{tabular} & $\begin{array}{c}- \\
7.0 \\
\end{array}$ & 2.1 & $\begin{array}{c}62 . \\
2\end{array}$ & - & $\begin{array}{c}37 . \\
8\end{array}$ \\
\hline Change of profit, thsd.hrn. per year & & $\begin{array}{l}72 \\
7.9\end{array}$ & $\begin{array}{c}- \\
69 . \\
7\end{array}$ & \begin{tabular}{|c|}
- \\
47 \\
4.4 \\
\end{tabular} & $\begin{array}{l}18 \\
3.7\end{array}$ & $\begin{array}{c}23 . \\
2\end{array}$ & $\begin{array}{c}53 . \\
0\end{array}$ \\
\hline $\begin{array}{c}\text { Change of profit per person, thsd.hrn. } \\
\text { per person per year }\end{array}$ & & $\begin{array}{l}62 \\
9.4\end{array}$ & $\begin{array}{c}- \\
69 . \\
5\end{array}$ & $\begin{array}{c}- \\
47 \\
4.4\end{array}$ & $\begin{array}{l}18 \\
3.4\end{array}$ & 7.1 & $\begin{array}{c}49 . \\
7\end{array}$ \\
\hline
\end{tabular}

Table 3: Financial results of activity, the size of the wage fund and the share of employees, who completed the training at PJSC Stakhanov Ferroalloy Plant in 2007-2013

\begin{tabular}{|c|c|c|c|c|c|c|c|}
\hline Indicator & 20 & 20 & 20 & 20 & 20 & 20 & 20 \\
& 07 & 08 & 09 & 10 & 11 & 12 & 13 \\
\hline Number of employees, people & 167 & 1687 & 161 & 1559 & 1575 & 1537 & 151 \\
6
\end{tabular}




\begin{tabular}{|c|c|c|c|c|c|c|c|}
\hline professional training, \% & & & & & & & \\
\hline Change in wage fund, thsd.hrn per year & & 29.7 & -7.6 & 36.4 & 14.3 & -3.8 & -1.9 \\
\hline $\begin{array}{c}\text { Change in wage fund per person, } \\
\text { thsd.hrn. per person per year }\end{array}$ & 28.6 & -3.6 & 41.6 & 13.1 & -1.4 & -0.5 \\
\hline $\begin{array}{c}\text { Change of net income. thsd.hrn. per } \\
\text { year }\end{array}$ & $\begin{array}{c}101 . \\
0\end{array}$ & - & 38.7 & 83.7 & -4.7 & -15.3 & $\begin{array}{c}- \\
17.0\end{array}$ \\
\hline $\begin{array}{c}\text { Change of profit, thsd.hrn. per year } \\
6\end{array}$ & $\begin{array}{c}777 . \\
76.4\end{array}$ & 61.5 & -51.0 & 45.0 & - \\
73.5 \\
\hline $\begin{array}{c}\text { Change of profit per person, thsd.hrn. } \\
\text { per person per year }\end{array}$
\end{tabular}

Table 4: Analysis of the relationship of financial results of enterprises, the wage fund and the share of employees who were trained at the enterprise in 2007-2013

\begin{tabular}{|c|c|c|c|}
\hline \multirow{2}{*}{$\begin{array}{c}\text { Financial results of } \\
\text { enterprise activity }\end{array}$} & $\begin{array}{c}\text { Pierson's linear correlation coefficient of de- } \\
\text { pendence of the share of employees who com- } \\
\text { pleted the training on financial results of enter- } \\
\text { prise activity in the current/ previous year }\end{array}$ \\
\cline { 2 - 4 } & $\begin{array}{c}\text { LLC Severodo- } \\
\text { netsk Plant of } \\
\text { Chemical non- } \\
\text { standardized } \\
\text { Equipment }\end{array}$ & $\begin{array}{c}\text { PJSC Krasnyi } \\
\text { Puch Machine- } \\
\text { building Plant }\end{array}$ & $\begin{array}{l}\text { PJSC Stakhanov } \\
\text { Ferroalloy Plant }\end{array}$ \\
\hline 1. Wage fund & $0.00 / 0.41$ & $0.12 / 0.64$ & $0.76 / 0.85$ \\
\hline 2. Wage fund per person & $0.27 / 0.06$ & $0.34 / 0.09$ & $0.78 / 0.82$ \\
\hline 3. Net income & $0.76 / 0.74$ & $0.07 / 0.71$ & $0.37 / 0.84$ \\
\hline 4. Profit & $0.43 / 0.75$ & $0.32 / 0.24$ & $0.24 / 0.35$ \\
\hline 5. Profit per person & $0.25 / 0.71$ & $0.33 / 0.31$ & $0.22 / 0.38$ \\
\hline
\end{tabular}

Discovered that the main factor affecting the amount of training at the enterprise is net income of the enterprise for the previous year (Table 4), and the dynamics of indicators, which characterize the personnel training is mostly determined by the change in wages fund of the enterprise for the previous year (Table 5). On the basis of this analysis it can be argued that decision-making on financing training is carried out taking into account net income of the enterprise for the previous year; the review of decisions on training is carried out under the influence of changes in the amount of wage fund.

Table 5: Analysis of the relationship of the dynamics of enterprise financial results, wage fund and change of the share of employees who completed the training at the enterprise in 2007-2013

\begin{tabular}{|c|c|c|c|}
\hline \multirow{2}{*}{$\begin{array}{l}\text { Dynamics of enterprise } \\
\text { financial results }\end{array}$} & \multicolumn{3}{|c|}{$\begin{array}{l}\text { Pierson's linear correlation coefficient of de- } \\
\text { pendence of the share of employees who com- } \\
\text { pleted the training on the dynamics of financial } \\
\text { results of enterprise activity in the current/ previ- } \\
\text { ous year }\end{array}$} \\
\hline & $\begin{array}{c}\text { LLC Severodo- } \\
\text { netsk Plant of } \\
\text { Chemical non- } \\
\text { standardized } \\
\text { Equipment }\end{array}$ & $\begin{array}{l}\text { PJSC Krasnyi } \\
\text { Luch Machine- } \\
\text { building Plant }\end{array}$ & $\begin{array}{l}\text { PJSC Stakhanov } \\
\text { Ferroalloy Plant }\end{array}$ \\
\hline $\begin{array}{l}\text { 1. Dynamics of wage } \\
\text { fund }\end{array}$ & $0.09 / 0.73$ & $0.13 / 0.84$ & $0.55 / 0.79$ \\
\hline $\begin{array}{l}\text { 2. Dynamics of wave } \\
\text { fund per person }\end{array}$ & $0.11 / 0.82$ & $0.13 / 0.71$ & $0.59 / 0.70$ \\
\hline $\begin{array}{l}\text { 3. Dynamics of net } \\
\text { income }\end{array}$ & $0.34 / 0.10$ & $0.04 / 0.82$ & $0.41 / 0.79$ \\
\hline 4. Dynamics of profit & $0.20 / 0.57$ & $0.33 / 0.41$ & $0.18 / 0.74$ \\
\hline $\begin{array}{l}\text { 5. Dynamics of profit } \\
\text { per person }\end{array}$ & $0.24 / 0.60$ & $0.25 / 0.36$ & $0.18 / 0.74$ \\
\hline
\end{tabular}

\section{Conclusion}

Thus, a retrospective link of relationship between organization and financing of training and its influence on the indicators of the enterprise activity was received. This information is important for the correction of the training process, but on its basis, it is difficult to carry out a forecast of the effectiveness of training. Therefore, there is a need to develop such a forecast in order to establish a certain link between training and its results in the form of certain rules and regularities.

\section{References}

[1] Becker GS (1965), A Theory of the Allocation of Time. The Economic Journal 75, 493-517.

[2] Buzko I \& Dyachenko Y (2012), Formation of methodological grounds for staff development. Actual Problems of Economics 129(3), 8-12.

[3] Buzko I, Dyachenko Y \&Nemashkalo O. (2011), Evaluation of human capital as a tool for management of human resource development. Actual Problems of Economics, 116(2), 117-123.

[4] Coleman S (1999), Social Capital in the Creation of Human Capital. Social Capital: A Multifaceted Perspective, Washington, DC: World Bank, pp. 13-39.

[5] Cooke P \& Morgan K. The associational economy: firms, regions, and innovation, Oxford: Oxford University Press, (2000).

[6] DiMaggio PJ \& Powell WW (1983), The iron cage revisited: Institutional isomorphism and collective rationality in organizational fields. American Sociological Review 48(2), 147-160.

[7] Fukuyama F. The Great Disruption: Human Nature and the Reconstitution of Social Order, New York: Free Press, (1999).

[8] Granovetter MS (1985) Economic Action and Social Structure: The Problem of Embeddedness. American Journal of Sociology 91, 481-510.

[9] Granovetter MS Getting a Job: A Study of Contacts and Career, Cambridge, MA: Harvard University Press, (1974).

[10] Kirkpatrick DL (1959), Techniques for evaluating training programs. Journal of the American Society for Training Directors 13(11), 3-9.

[11] Kirkpatrick DL (1959), Techniques for evaluating training programs: Part 2 - Learning. Journal of the American Society for Training Directors 13(12), 21-26.

[12] Kirkpatrick DL (1960), Techniques for evaluating training programs: Part 3 - Behavior. Journal of the American Society for Training Directors 14(1), 13-18.

[13] Kirkpatrick DL (1960), Techniques for evaluating training programs: Part 4 - Results. Journal of the American Society for Training Directors 14(2), 28-32.

[14] Knorringa P \& van Staveren I Social Capital for Industrial Development: Operationalizing the Concept, Vienna: United Nations Industrial Development Organization, (2006).

[15] Milner BZ Knowledge Management, Moscow, INFRA-M, (2003).

[16] Nenkov N, Dyachenko Y, Dimitrov G \& Koeva K (2016) Artificial Intelligence Technologies for Personnel Learning Management Systems. 2016 IEEE 8th International Conference on Intelligent Systems. Proceedings, Sofia, Bulgaria, 189-194.

[17] Nenkov N, Petrova M, Dyachenko Y, Bondarenko G \& Pustovit V (2017), Intelligent and Cognitive Technologies in Education of International Economic Relations Students and Human Resource Development: Methodology in Language Teaching and Distance Learning. European Journal of Sustainable Development 6(4), 353-360.

[18] Nenkov N, Sushchenko O \& Dyachenko Y (2017), Role of chief information officer within the system of human resource development in service organizations (tourism). Economic Annals-XXI 165(5-6), 97-103.

[19] Pechenkin A (2005), Evaluation of the effectiveness of e-learning projects. 2nd Moscow International Exhibition and Conference on $e$ Learning eLearnExpo Moscow 2005, available online: http://www.bitsexpo.ru/files/2005/conf_materials/Pechenkin.pps, last visit: 01.01.2010.

[20] Phillips JJ Handbook of Training Evaluation and Measurement Methods Houston, Texas: Gulf Publishing Company, (1983).

[21] Porter M (2000), Location, competition and economic development; local clusters in a global economy. Economic development quarterly 14(1), 15-34.

[22] Putnam RD Bowling Alone: The Collapse and Revival of American Community. New York: Simon \& Schuster, (2000).

[23] Schrader S (1992), Informal Technology Transfer between Firms: Cooperation Through Information Trading. Research Policy 20, 153-170.

[24] The Millennium Development Goals, United Nations, (2000), available online:

http://www.un.org/en/mdg/summit2010/pdf/List+of+MDGs+English.pd f, last visit: 15.06.2018.

[25] Von Hippel E Sources of Innovation, N.Y.: Oxford University Press, (1988)

[26] Vorotynceva T \& Nedelin E We are building the personnel training system. A Practical Guide for Training Professionals, SPb, Rech' (2008).

[27] Wallis JJ \& North DC (1986), Measuring the Transaction Sector in the American Economy, 1870-1970. Long-term factors in American Economic Growth. Studies in Income and Wealth Series 51, 195-161. 